\title{
Konposatu fenolikoak eta osasuna
}

\section{(Phenolic compounds and health)}

\author{
Iñaki Milton-Laskibar*, Alfredo Fernández-Quintela, María Puy Portillo \\ Farmazia eta Elikagaien Zientziak Saila. Farmazia Fakultatea, Arabako Campusa. \\ Euskal Herriko Unibertsitatea (UPV/EHU) \\ CIBERobn, Instituto de Salud Carlos III. 28029 Madrid \\ *inaki.milton@ehu.eus
}

DOI: $10.1387 /$ ekaia.17818

Laburpena: Konposatu fenolikoak, egitura kimikoaren arabera sailkatu daitezkeen zenbait sustantziaz osatutako talde zabal bat dira. Landareek ekoizten dituzte bigarren mailako metabolito gisa, erantzun modura erradiazio ultramorea, patogenoak, kalte oxidatiboa eta ingurumen baldintza zailak bezalako erasoei aurre egiteko. Hori dela eta, modu naturalean daude landare jatorriko elikagaietan, hala nola frutetan, barazkietan, fruitu lehorretan, olioetan, tean eta ardoan. Konposatu fenoliko gehienak ester, glukosido edo polimero gisa aurkitzen dira elikagaietan, eta ondorioz hestean hidrolizatu behar dira xurgatuak izan baino lehen. Gibelean eta heste meharrean konposatu fenolikoak metabolizatzen dira II faseko entzimen eraginez. Gibelean eratzen diren metabolitoen zati bat, heste meharrera jariatuko da behazun bideetatik, eta bertan berriro xurgatuak izateko dekonjugatu egingo dira, edota kolonerako bidea jarraituko dute. Behin heste lodian, hesteko mikrobiotak konposatu fenolikoak metabolizatuko ditu. Prozesu hauen ondorioz, konposatu fenolikoen bioerabilgarritasuna txikia da. Konposatu fenolikoen eta beren metabolitoen iraizpena, gernu bidez gertatzen da nagusiki. Antioxidazio-ahalmen handia duten konposatu bioaktiboak dira. Azken urteetan, eragiten dituzten antioxidazio efektuengatik, eta beste mekanismo batzuengatik, hainbat gaixotasunen garapenaren aurkako efektu onuragarriak egotzi zaizkie: minbizia, gaixotasun kardiobaskularrak eta neuroendekapenezko gaixotasunak.

Hitz gakoak: Konposatu fenolikoa, antioxidatzailea, metabolismoa, osasuna.

Abstract: Phenolic compounds make up a wide group of different substances that can be grouped together by its chemical structure. They are synthesized by plants as secondary metabolites in response to aggressions such as ultraviolet radiation, pathogens, oxidative damage and rough climatic conditions. For this reason, they can be found in plant based foodstuffs, such as fruits, vegetables, nuts, oils, teas and wines. The majority of the phenolic compounds present on food are found as esters, glycosides or poly- 
mers, which have to be hydrolyzed in the gut before being absorbed. By the action of the so called phase II enzymes, the phenolic compounds are metabolized in the small bowel and in the liver. Some of the metabolites produced in the liver are secreted to the small bowel through the bile duct, where they will be either deconjugated to be reabsorbed or reach the colon. Once in the large bowel, the phenolic compounds are further metabolized by the gut microbiota. As a consequence of all these processes, the bioavailability of the phenolic compounds is low. The excretion of the phenolic compounds and their metabolites is basically done through the urine. They are bioactive compounds with high antioxidant capacity. In the last years, different beneficial effects against the development of some illnesses (cancer, cardiovascular and neurodegenerative diseases) were attributed to these compounds, in part because of their antioxidant effect, and also due to other different mechanisms.

Keywords: Phenolic compounds, antioxidant, metabolism, health.

\section{EGITURA KIMIKOA ETA ELIKAGAI ITURRIAK}

Konposatu fenolikoak (polifenol ere deituak), multzo zabal bat dira, eraztun fenoliko bat edo gehiago edukitzeagatik bereizten diren sustantziez osatua. Sustantzia hauek, egitura kimikoaren arabera, talde ezberdinen ba-

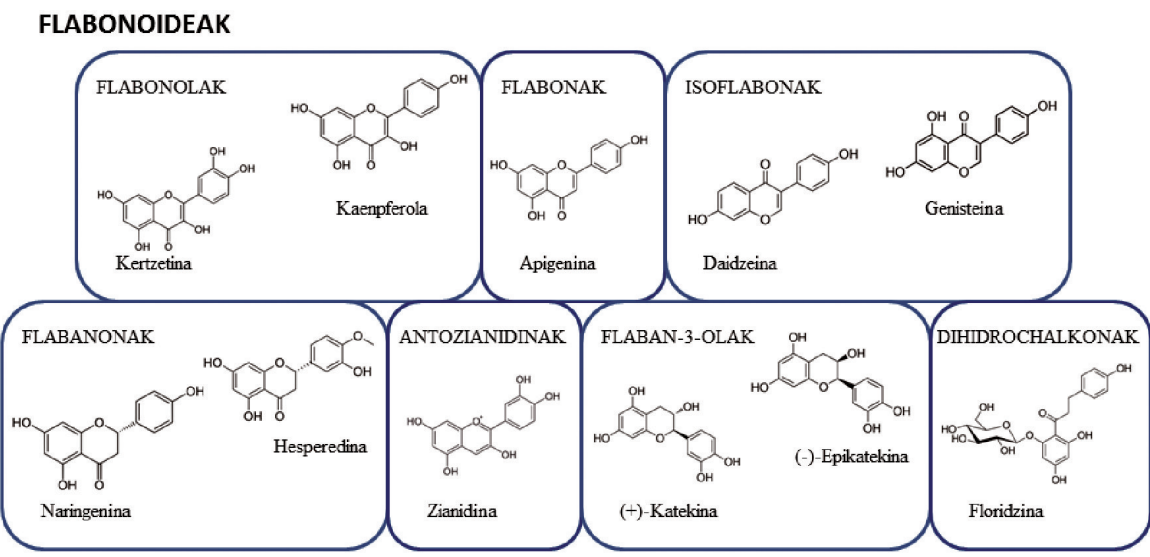

EZ FLABONOIDEAK

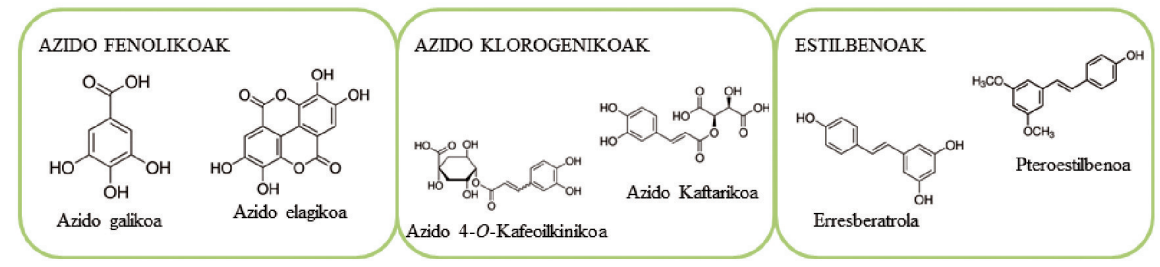

1.irudia. Konposatu fenolikoen sailkapena. 
rruan sailkatuta daude. Haien artean, ondo bereizi behar dira flabonoideak (flabonolak, flabonak, isoflabonak, flabanonak, flaban-3 olak, antozianidinak eta dihidrochalkonak) eta ez flabonoideak (estilbenoak, azido klorogenikoak eta azido fenolikoak) (1. irudia) [1]. Egitura kimikoaren arabera, konposatu hauek zenbait efektu onuragarri eragin ditzakete organismoan.

Konposatu hauek, landareek ekoizten dituzte bigarren mailako metabolito gisa, erradiazio ultramorea, patogenoak, kalte oxidatiboa eta ingurumen baldintza zailak bezalako erasoei aurre egiteko. Hori dela eta, modu naturalean daude landare jatorriko elikagaietan, hala nola frutetan, barazkietan, fruitu lehorretan, olioetan, tean eta ardoan (ikusi 1. taula). Molekula hauek, fruta eta barazkiei kolorea emateaz gain, hauen garraztasunean, astringentzian, zaporean, aroman eta egonkortasun oxidatiboan ere eragiten dute.

Asko dira elikagai hauetan dauden konposatu fenolikoen kantitatean eragina duten faktoreak. Hauen artean, landarearen berezko faktore intrintsekoak nabarmendu behar dira. Hauek, polifenolen edukian alde handiak egotea eragin dezakete, ez bakarrik espezie ezberdinen artean, baita produktu beraren aldaeren artean ere. Adibidez, $300 \mathrm{mg}$ polifenol daude Lollo rosso motako uraza baten 100 gramo elikagaitan, baina Iceberg motako batean, 100 gramo elikagaitan $10 \mathrm{mg}$ polifenol besterik ez dago. Laborantza eta uzta ondorengo kontserbazio-baldintzekin zerikusia duten faktore estrintseko garrantzitsuak ere badaude (landutako lurraren konposizioa, uraren eskuragarritasuna, tenperatura eta eguzkipeko esposizioa). Jakien heltze mailak ere eragin handia dauka, batik bat frutetan. Gainera, elikagaiak hartzeko moduak konposatu fenolikoen ingestioa baldintzatu dezake. Horrela, frutak zuritzean, haien konposatu fenoliko edukia nabarmen murriztuko dugu. Bestalde, uretan edo mikrouhin-labe batean egosi diren barazkiek, oso polifenol eduki ezberdinak izan ditzakete [2].

Ez da lan erraza elikagai ezberdinek dituzten konposatu fenolikoen kantitateak zehaztea. Alde batetik, mota asko daude, eta bestetik, egitura kimiko bakoitzak balorazio baldintza ezberdinak behar ditu. Eduki hau, Folinen teknikaren bidez aztertu ohi da, ahalmen antioxidatzailea neurtuta. Hala ere, teknika honek badu muga garrantzitsu bat; polifenolak ez diren beste konposatu batzuen ahalmen antioxidatzailea ere neurtzen duela, eta ondorioz balio altuagoak lortzen dira benetan elikagaietan daudenak baino. Egoera honen aurrean, Phenol Explorer (www.phenol-explorer.eu) izeneko datu-basea sortu zen, eta bertan 452 elikagai ezberdinen batez besteko polifenol edukiak bilduta daude [3]. Horretarako, 502 polifenol aztertu ziren banaka, nagusiki teknika kromatografiakoak erabiliz. Datu-base honetan oinarrituta, polifenoletan aberatsenak diren 100 elikagaiak biltzen dituen zerrenda argitaratu zen 2010. urtean [4]. 
1. taula. Polifenol edukia ohiko kontsumokoak diren elikagaietan (Pérez-Jiménez et al., 2010).

\begin{tabular}{|c|c|c|}
\hline Elikagaia & Elikagai taldea & $\begin{array}{c}\text { Kantitatea }^{\mathrm{a}} \\
(\mathrm{mg} / 100 \mathrm{~g} \text { edo } \mathrm{mg} / 100 \mathrm{~mL})\end{array}$ \\
\hline Baratxuria & $\begin{array}{l}\text { Zapore indartzaileak/aroma- } \\
\text { tizatzaileak }\end{array}$ & 15188 \\
\hline Menda (lehorra) & $\begin{array}{l}\text { Zapore indartzaileak/aroma- } \\
\text { tizatzaileak }\end{array}$ & 7920 \\
\hline Koko irina & Kokoaren eratorriak & 3448 \\
\hline Txokolate beltza & Kokoaren eratorriak & 1664 \\
\hline Linazia & Haziak & 1228 \\
\hline Gaztainak & Fruitu lehorrak & 1215 \\
\hline Erromeroa (lehorra) & $\begin{array}{l}\text { Zapore indartzaileak/aroma- } \\
\text { tizatzaileak }\end{array}$ & 1018 \\
\hline Hurrak & Fruitu lehorrak & 495 \\
\hline Aranak & Frutak & 377 \\
\hline Oliba berdeak & Landare jatorrikoak & 346 \\
\hline Gereziak & Frutak & 274 \\
\hline Orburuak & Ortuariak & 260 \\
\hline Masusta & Frutak & 260 \\
\hline Esnedun txokolatea & Kokoaren eratorriak & 236 \\
\hline Marrubia & Frutak & 235 \\
\hline Kafea (iragazia) & Edari alkoholgabeak & 214 \\
\hline $\begin{array}{l}\text { Ale osoko irina (gari gogo- } \\
\text { rrarena) }\end{array}$ & Zerealak & 201 \\
\hline Aranpasa & Frutak & 194 \\
\hline Almendra & Fruitu lehorrak & 187 \\
\hline Mahats gorria & Frutak & 169 \\
\hline Tipula gorria & Ortuaria & 168 \\
\hline Sagarra & Frutak & 136 \\
\hline Ziazerbak & Barazkiak & 119 \\
\hline Te beltza & Edari alkoholgabeak & 102 \\
\hline Ardo beltza & Edari alkoholdunak & 101 \\
\hline Te berdea & Edari alkoholgabeak & 89 \\
\hline Ale osoko gari irina & Zerealak & 71 \\
\hline Sagar zukua & Edari alkoholgabeak & 68 \\
\hline
\end{tabular}


Konposatu fenolikoak eta osasuna

\begin{tabular}{l|l|c}
\hline \multicolumn{1}{c|}{ Elikagaia } & \multicolumn{1}{|c}{ Elikagai taldea } & $\begin{array}{c}\text { Kantitatea }^{\mathrm{a}} \\
(\mathrm{mg} / 100 \mathrm{~g} \text { edo mg/100 } \mathrm{mL})\end{array}$ \\
\hline Granada zukua & Edari alkoholgabeak \\
Oliba olio birjina & Olioak eta gantzak & 62 \\
Babarrun beltza & Lekaleak & 59 \\
Mertxika & Frutak & 59 \\
Mahats zukua & Edari alkoholgabeak & 53 \\
Babarrun zuria & Lekaleak & 51 \\
Laranja zukua & Edari alkoholgabeak & 46 \\
Brokolia & Ortuariak & 45 \\
Albertxikoa & Frutak & 34 \\
Zainzuria & Ortuariak & 29 \\
Intxaurra & Fruitu lehorrak & 28 \\
Patata & Ortuariak & 28 \\
Perrexila & Zapore indartzaileak/aroma- & 25 \\
Brinoia & tizatzaileak & 25 \\
Eskarola & Frutak & 24 \\
Uraza & Barazkiak & 23 \\
Esnedun txokolate edaria & Barazkiak & 21 \\
Soja esnea & Edari alkoholgabeak & 17 \\
Udarea & Edari alkoholgabeak & 17 \\
Mahats berdea & Frutak & 15 \\
Azenarioa & Frutak & 14 \\
Ozpina & Ortuariak & 13 \\
Ardo zuria & Zapore indartzaileak/aroma- & 10 \\
Ardo gorria & tizatzaileak & 10 \\
\hline & Edari alkoholdunak & Edari alkoholdunak \\
\hline
\end{tabular}

a Polifenolen eta proantozianidina oligomeroen banakako edukiaren gehiketa (errendimendu altuko kromatografia likido bidez neurtua).

\section{KONPOSATU FENOLIKOEN METABOLISMOA}

Polifenolen metabolismoa, denentzat komuna den erreakzio segida baten bidez gertatzen da. Erreakzio hauetan konposatu fenolikoak hidrofilikoagoak egiten dira, eta erraztu egiten da beren gernu edo behazun bidezko iraizpena. Konposatu fenoliko gehienak ester, glukosido edo polimero gisa 
aurkitzen dira, ezin daitezkeelarik zuzenean xurgatuak izan. Glukosido gehienek urdaileko hidrolisi azidoa jasaten dute, hestera bere horretan iristen direlarik. Bertan, $\beta$-glukosidasa eta laktasa-florizin hidrolasa bezalako entzimek hidrolizatzen dituzte, beren xurgapena ahalbidetuz $[1,5]$.

Heste meharrean bertan, konposatu fenolikoak metabolito bihurtzen hasten dira xurgatuak izan aurretik, II faseko entzimen eraginagatik (sulfotransferasak, uridin-5' -difosfato glukuronosiltransferasak eta katekol-Ometiltransferasak nagusiki). Hauek metilazio, sulfatazio eta glukuronizazio prozesuak bideratuko dituzte. Behin gibelean, entzima berdinek katalizatutako metabolizazio prozesu berri bat gertatzen da. Prozesu hauen ondorioz, nahiko baxuak izaten dira plasma eta ehunetan agertzen diren jatorrizko konposatu fenolikoen kontzentrazioak, euren metabolitoenak altuagoak direlarik. Hori dela eta, bada eragozpen larri bat konposatu fenolikoak molekula bioaktibo bezala erabili ahal izateko duten bioerabilgarritasun baxua. Gibelean eratu diren metabolitoen zati bat, heste meharrera jariatuko da behazun bideetatik; bertan, berriro xurgatuak izateko dekonjugatu egingo dira, edota kolonerako bidean aurrera egingo dute. Behin heste lodian, bertako mikrobiotak konposatu fenolikoak metabolizatuko ditu. Konposatu fenolikoen eta beren metabolitoen iraizpena, gernu bidez ematen da nagusiki. Azkenik, xurgatu ez diren konposatu fenolikoak edota koloneko bakterioek eraldatu ez dituztenak, gorozkiekin batera kanporatzen dira (2. irudia) [1,5].

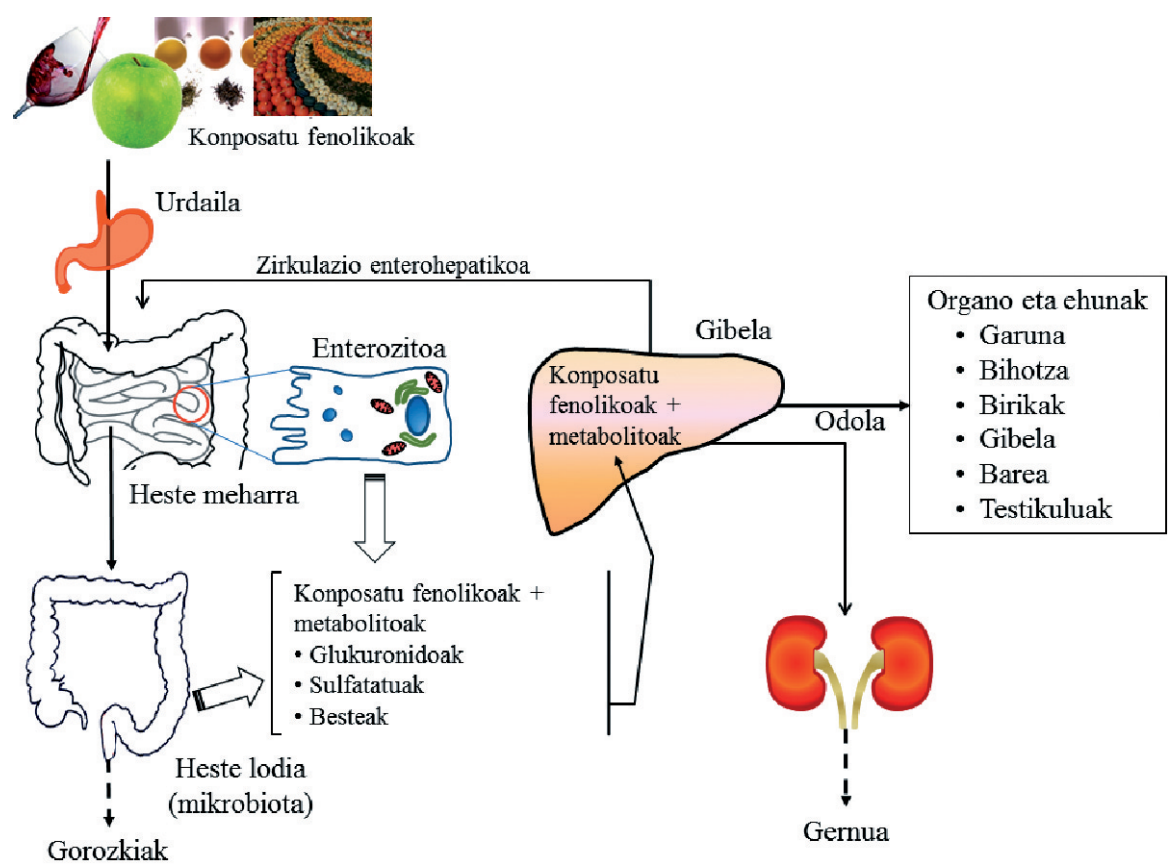

2. irudia. Konposatu fenolikoen metabolismo orokorra. 
Konposatu fenolikoak eta osasuna

\section{KONPOSATU FENOLIKOEN EFEKTUAK OSASUNEAN}

Polifenolak, oxidazioaren aurkako konposatu bioaktiboak dira, eta interes handikoak bilakatu dira nutrizioaren ikuspuntutik. Izan ere, eragiten dituzten efektuak garrantzitsuak dira osasunean ez ezik, zenbait gaixotasunek eragindako asaldadura funtzional eta egiturazkoen prebentzioan ere.

Azken urteetan, polifenolak, estres oxidatibo deritzon zelula oxidazio prozesuen handitzearekin zerikusia duten zenbait gaixotasunen (minbizia, gaixotasun kardiobaskularrak eta neuroendekapenezkoak) garapenaren aurkako eragin onuragarria izan dezaketela esan izan da $[1,6]$.

Kasu gehienetan, ez dago guztiz argi zein diren elikagaietan dauden konposatu fitokimikoek osasun-efektu onuragarriak eragiteko ustez jarraitzen dituzten mekanismoetako asko. Zeluletan eta animalietan egindako ikerketetan, jarduera biologiko mota asko ikusi dira. Aniztasun hau, talde beraren barruan dagoen egitura kimikoen aberastasunagatik ematen da.

Konposatu fenolikoek eragiten dituzten onurak areagotzeko, funtsezkoa da molekula hauetan aberatsak diren orotariko elikagaiak kontsumitzea. Modu honetan, efektu sinergikoak lortu ahalko dira eta ondorioz, osasunean sortuko diren onurak, banakako efektuen gehiketak eragindakoak baino handiagoak izango dira.

\subsection{Konposatu fenolikoen efektuak patologia kardiobaskular eta zerebrobaskularretan}

Hainbat epidemiologia-ikerketa egin dira bihotz-zainetako eta burmuinzainetako gaixotasunen garapenean dieta-ohiturek eragiten duten efektua ebaluatzeko. Ikerketa hauek, gizabanakoen dietak eta ondorengo urteetan miokardio-infartuek eragindako heriotza tasa aztertu dituzte. Nahiz eta oraindik konposatu fenolikoen efektuak eztabaidagai izan, epidemiologiaikerketa gehienek erakutsi dute alderantzizko erlazioa dagoela konposatu hauen kontsumoaren eta miokardio-infartuek eragindako heriotza tasaren artean [7].

Efektu hauen mekanismoak mota askotakoak dira. Alde batetik, konposatu fenolikoek efektu baso-zabaltzaileak eragiten dituzte, nagusiki endotelioko oxido nitrikoaren (ON) askapenagatik. Izan ere, ON-a, tonu baskularraren erregulazioan garrantzi handia duen bitartekaria da. Efektu baso-zabaltzaile honetan parte hartzen dute bai angiotentsinaren entzima bihurtzailearen (AEB) inhibizioak [8,9], bai eta konposatu fenolikoen oxidazioaren aurkako efektu antioxidatzaileak ere [10]. Bestetik, profil lipidikoa hobetzen dute, dentsitate baxuko lipoproteinak (LDL) murriztuz eta dentsitate altukoak (HDL) ugarituz. 
Honek, arteriosklerosiaren garapena ekiditen du. Gaixotasun hau, denboran zehar arterien hormetan pilatzen diren lipidoek eragindako buxaduragatik sortzen da. Denborarekin, lipido hauek endotelioa zeharkatzen dute eta oxidatu egiten dira. Makrofagoek fagozitatzen dituztenean, molekula oxidatu hauek zelula apartsu bihurtzen dira. Gainera, hantura eta muskulu leuneko zelulen proliferazioa gertatzen da. Honek, zelulaz kanpoko matrizearen gehiegizko galera eta leukozitoak, monozitoak eta $\mathrm{T}$ linfozitoak endotelio baskularrera atxikitzea eragiten du. Prozesu hauen guztien ondorioz, arterien buxadura gertatzen da. Prozesu aterogenikoaren bukaeran, plaka arteriosklerotikoaren haustura eta plaketen aktibazioa gertatzen dira, eta ondorioz tronboak eragiten dituzte. Egoera honetan, profil lipidikoa hobetzeaz gain, konposatu fenolikoek beste hainbat efektu onuragarri bideratzen dituzte: plaketen pilaketaren murrizketa, LDL-en oxidazioaren inhibizioa, atxikimendu molekulen eta hantura markatzaileen murrizketa, eta oxidazio-kaltearen prebentzioa $[11,12]$. Zenbait aurkikuntzek erakutsi dute pazienteen aurrekari genetikoek ere eragina izan dezaketela.

\subsection{Konposatu fenolikoen efektuak minbizian}

Epidemiologia-ikerketek erakutsi dute fruta eta barazkien kontsumo altua zenbait minbiziren agerpen baxuagoarekin lotuta dagoela: batik bat urdailekoa, heste gorrikoa, birikakoa, ahokoa, faringekoa, endometriokoa, pankreakoa eta kolonekoa [2].

Efektu onuragarri hauetan parte har dezaketen zenbait mekanismo deskribatu dira. Adibidez, flabonoide askok estrogenoen aurka erakutsitako aktibitatea lagungarria izan liteke estrogeno horien menpekoak diren tumoreak garatzeko probabilitateak murrizten [13]. Badira era berean beste zenbait polifenol, tumore zeluletan guztiz desregulatuta dagoen zelula-proliferazioa inhibitzeko gai direnak. Proliferazioaren aurkako efektu honek iradokitzen du, konposatu fenolikoek zelularen ziklo zelularra inhibitzeko edota apoptosia eragiteko gaitasuna dutela. Proliferazioaren inhibizio hau, in vitro frogatu da hainbat tumore zelula motatan. Hala ere, nahiz eta zeluletan polifenolek proliferazioaren aurka dituzten efektuak argi eta garbi frogatu diren, datu gutxi daude in vivo gertatzen denari buruz, eta ia ezer ez jarduera honen garrantzi klinikoari dagokionez [14]. Oxidazioaren aurkako aktibitateari esker, polifenolek ahalmena dute DNAren oxidazio-kaltea (mutazioak sor ditzakeena) inhibitzeko, eta ondorioz, minbizi aurkako babesa emateko [15]. Kasu honetan ere, in vivo lortutako emaitzak oso urriak dira oraindik. Badago kartzinogenesia prebenitzeko beste mekanismo bat, zenbait entzimen jardueran eraginez lortzen dena. Honela, konposatu fenolikoek, kartzinogenoen detoxifikazioa eragiten duten entzimak aktiba ditzakete [16], edota sustantzia prokartzinogenoetatik abiatuta kartzinogenoak sortzen dituztenak inhibi ditzakete. 
Konposatu fenolikoak eta osasuna

\subsection{Konposatu fenolikoen efektuak neuroendekapenezko patologietan}

Edpidemiologia-ikerketek, konposatu fenolikoetan aberatsa den dieta bat hartzearen eta Alzheimerra, zahartzaroko dementzia eta Parkinsona bezalako neuroendekapenezko gaixotasunen artean, alderantzizko korrelazio bat dagoela erakusten duten ebidentzia zientifikoak aurkitu dituzte [17, 18]. Gaixotasun hauen oinarria oxidazio-estresean egon litekeela proposatu denez, konposatu fenolikoek oxidazioaren aurka erakutsi duten eraginkortasuna babes-faktore garrantzitsua izan liteke. Bestalde, patologia hauek, solugaitzak diren agregatu proteikoen bitartez garatzen dira. Adibidez, Alzheimer gaixotasunean gertatzen den beta-amiloide sustantziaren metaketa aipatu daiteke. Hori dela eta, azpimarratzekoa da konposatu fenolikoen gaitasuna agregatu hauek desegiteko. Honela, neuronetan, oreka egokia ahalbidetzen da gaizki tolestutako proteinen eta beren degradazioaren artean [19].

Muga hematoentzefalikoa gainditzeko duten iragazkortasun urria da polifenolek patologia hauetan eragina izateko oztopo nagusiena (aurrez aipatutako bioerabilgarritasun baxuarekin batera). Hala ere, nabarmendu behar da konposatu fenolikoen metabolitoen bidez gauzatzen direla garunean eragiten diren zenbait efektu [19].

\subsection{Konposatu fenolikoen efektuak obesitatean, intsulinarekiko erresistentzian eta diabetesean}

Lan batzuek frogatu dute zenbait konposatu fenolikok ahalmena dutela gorputzeko gantz-pilaketa ekiditeko. Hori dela eta, proposatu da konposatu fenolikoak obesitatearen aurkako molekula bezala erabil litezkeela [20]. Hala ere, gaurdaino argitaratu diren lan gehienak animalietan egin direnez, oso handiak dira lortutako emaitzak gizakietara estrapolatzeko mugak. Bestalde, lan gehienak gizentze-dietekin elikatutako animalietan oinarritu direnez, ondorio modura, konposatu hauek gehiegizko gantz pilaketa mugatzeko duten ahalmena ikusi izan da (eta ez hainbeste aurretiaz metatutako gantza murriztekoa).

Animalia modelo hauek erabiliaz, hainbat mekanismo proposatu dira konposatu hauek gorputz-gantzean dituzten efektuak azaltzeko. Alde batetik, ahalmena dute adipozitoetako gantz-metaketan zerikusia duten prozesu metabolikoak murrizteko, hala nola lipogenesia, odoleko lipidoak hartzea eta triglizeridoen muntaia. Badirudi, halaber, ehun adiposoko gantzen mobilizazioa eragiteko gaitasuna dutela, gai honen inguruan oraindik adostasunik ez badago ere. Argi frogatu da era berean nola gertatzen den adipogenesiaren inhibizioa, hau da, aurre adipozitoen proliferazioaren eta hauen ondorengo heltze prozesuaren (adipozito heldu bihurtzearen) murrizketa. Azkenik, ikusi da zenbait konposatu fenolikok ahalmena dutela gantz-ehun arrean termogenesia, eta honen ondoriozko energi-gastua eragiteko $[21,22]$. 
Halaber, kontutan izan behar da, konposatu fenolikoek beste ehunetan sortzen dituzten efektuek ehun adiposoan gertatzen den gantz metaketa murrizten lagundu dezaketela. Honela, gibeleko eta eskeleto-muskuluko gantz azidoen oxidazioa kitzikatzeak, lagundu dezake ehun adiposoan suertatzen den triglizeridoen sintesia eta metaketarako eskuragarri dauden gantz azidoak murrizten. Bestalde, hesteetan gertatzen den glukosaren xurgapena murrizteak, eskuragarri dagoen energia murriztuko du.

Obesitateak, hainbat komorbilitate eragiten ditu, besteak beste gluzemiaren kontrolaren asaldadura. Hau, hasieran, intsulinarekiko erresistentzia bezala agertzen da, eta denborarekin 2 motako diabetes bilakatzen da. Animalietan egindako lan batzuek erakutsi dute zenbait konposatu fenolikok ahalmena dutela aurrez aipatutako bi egoera hauek ekiditeko. Horretarako, glukosa zeluletan sartzen duten GLUT4 eta GLUT1 garraiatzaileen kopurua eta beren zelula-gainazalerako translokazioa handitzen dute, baita gibeleko glukogeno metaketa ere. Lehen aipatutako heste bidezko glukosa-xurgapenaren murrizketak ere lagundu dezake efektu hau lortzen. Gainera, hauetako zenbait konposatuk ahalmena dute hartzaile estrogenikoei zeharka eragiteko, eta horrela, gluzemiaren kontrola hobetzeko [23].

\section{BIBLIOGRAFIA}

[1] Del Río D., Rodríguez-Mateos A., Spencer J.P.E., Tognolini M., Borges G. eta Crozier A. 2013. «Dietary polyphenolics in human health: structures, bioavailability and evidence of protective effects against chronic diseases». Antioxidants \& Redox Signaling, 18, 1818-1892.

[2] Tomás-Barberán F. A. 2003. «Los polifenoles de los alimentos y la salud». Alimentación, Nutrición y salud, 10, 41-53.

[3] Neveu V., Pérez-Jiménez J., Vos F., Crespy V., Du Chaffaut L., Mennen L., Knox C., Eisner R., Cruz J., Wishart D. eta Scalbert A. 2010. «Phenol-Explorer: an online comprehensive database on polyphenol contents in foods». Database, doi: 10.1093/database/bap024.

[4] Pérez-Jiménez J., Neveu V., Vos F. eta Scalbert A. 2010. «Identification of the 100 richest dietary sources of polyphenols: an application of the PhenolExplorer database». European Journal of Clinical Nutrition, 64, S112-S120.

[5] Crozier A., Jaganath I.B. eta Clifford M.N. 2009. «Dietary phenolics: chemistry, bioavailability and effects on health». Natural product Reports, 26, 1001-1043.

[6] Ríos-Hoyo A., Cortés M.J., Ríos-Ontiveros H., Meaney E., Ceballos G. eta Gutiérrez-Salmeán G. 2014. "Obesity, Metabolic Syndrome, and Dietary Therapeutical Approaches with a Special Focus on Nutraceuticals (Polyphenols): A Mini-Review». International Journal for Vitamin and Nutrition Research, 84, 113-123. 
[7] Hertog M.G.L., Kromhout D., Aravanis C., Blackburn H. eta Buzina R. 1995. «Flavonoid intake and long-term risk of coronary heart disease and cancer in the Seven Countries Study». Archives of Internal Medicine, 155, 381-386.

[8] Andriambeloson E., Kleschyov A.L., Muller B., Beretz A., Stoclet J.C. eta Andriantsitohaina R. 1997. «Nitric oxide production and endothelium- dependent vasorelaxation induced by wine polyphenols in rat aorta». British Journal of Pharmacology, 120, 1053-1058.

[9] Ojeda D., Jiménez-Ferrer E., Zamilpa A., Herrera-Arellano A., Tortoriello J. eta Alvarez L. 2010. «Inhibition of angiotensin convertin enzyme (ACE) activity by the anthocyanins delphinidin- and cyanidin-3-O-sambubiosides from Hibiscus sabdariffa». Journal of Ethnopharmacology, 127, 7-10.

[10] Quiñones M., Miguel M. eta Aleixandre A. 2012. «Los polifenoles, compuestos de origen natural con efectos saludables sobre el sistema cardiovascular». Nutrición Hospitalaria, 27, 76-89.

[11] Wilcox L.J., Borradaile N.M., de Dreu L.E. eta Huff M.W. 2001. «Secretion of hepatocyte apoB is inhibited by the flavonoids, naringenin and hesperetin, via reduced activity and expression of ACAT2 and MTP». Journal of Lipid Research, 42, 725-734.

[12] Pal S., Ho N., Santos C., Dubois P., Mamo J., Croft K. eta Allister E. 2003. «Red wine polyphenolics increase LDL receptor expression and activity and suppress the secretion of ApoB100 from human HepG2 cells». The Journal of Nutrition, 133, 700-706.

[13] Miksicek R.J. 1995. «Estrogenic flavonoids: structural requirements for biological activity». Proceedings of the Society for Experimental Biology and Medicine, 208, 44-50.

[14] Birt D.F., Hendrich S. eta Wang W. 2001. «Dietary agents in cancer prevention: flavonoids and isoflavonoids». Pharmacology \& Therapeutics, 90, 157177.

[15] Omenn G.S. 1995. «What accounts for the association of vegetables and fruits with lower incidence of cancers and coronary heart disease?». Annals of Epidemiology, 5, 333-335.

[16] Talalay P., Fahey J.W., Holtzclaw W.D., Prestera T. eta Zhang Y. 1995. «Chemoprotection against cancer by phase 2 enzyme induction». Toxicology Letters, 82-83, 173-179.

[17] Ho L. eta Pasinetti G.M. 2010. «Polyphenolic compounds for treating neurodegenerative disorders involving protein misfolding». Expert Review of Proteomics, 7, 579-589.

[18] Pasinetti G.M. eta Ho L. 2010. «Role of grape seed polyphenols in Alzheimer's disease neuropathology». Nutrition and Dietary Supplements, 2, 97-103.

[19] Hajieva P. 2017. «The effects of polyphenols on protein degradation pathways: implications for neuroprotection». Molecules, 22, 159.

[20] Aguirre L., Fernández-Quintela A., Arias N. eta Portillo M.P. 2014. «Resveratrol: anti-obesity mechanisms of action». Molecules, 19, 18632-18655. 
[21] Pan H., Gao Y. eta Tu Y. 2016. «Mechanisms of body weight reduction by black tea polyphenols». Molecules, 21, 1659.

[22] Lu B., Li M. eta Yin R. 2016. «Phytochemical Content, Health Benefits, and Toxicology of Common Edible Flowers: A Review (2000-2015)». Critical Reviews in Food Science and Nutrition, 56 (Suppl 1), S130-S148.

[23] Szkudelska K. eta Szkudelski T. 2010. «Resveratrol, obesity and diabetes». European Journal of Pharmacology, 635, 1-8. 